\title{
A ORIGEM BIOPOLÍTICA DO DIREITO TRIBUTÁRIO
}

\author{
THE BIOPOLITICS ORIGIN OF TAXATION LAW
}

\author{
Farah de Sousa Malcher ${ }^{1}$ \\ Jean-François Yves Deluchey ${ }^{2}$
}

\section{RESUMO}

Analisamos a origem do tributo na Modernidade e as razões que o legitimaram no contexto da governamentalidade neoliberal descrita por Foucault. Traçamos um paralelo entre tributação e biopoder sob outro prisma que não o do contratualismo. Soma-se a tal reflexão a associação de Agamben entre exceção soberana e vida nua. Para ele, o núcleo que sustenta a criação de direitos está intrinsecamente relacionado à suspensão de direitos. O controle da vida está por detrás da história do tributo. O objetivo foi discutir o fundamento biopolítico do tributo e seus reflexos no gozo das liberdades públicas e no desenvolvimento social.

Palavras-chave: Tributo; Biopolítica; Modernidade; Contratualismo; Desenvolvimento Social.

\begin{abstract}
We analyze the origin of the tribute in modernity and the reasons that legitimised in the context of the neo-liberal governmentality described by Foucault. Plot a parallel between taxation and biopower under another way than the contractualism. In addition, such considerations the association of Agamben between sovereign exception and life. For him, the core that supports creation of rights is intrinsically related to suspension of rights. The control of one's life is behind the history of tribute. The objective was discuss the merits of the biopolitical tribute and their reflections in the enjoyment of public freedoms and in social development.
\end{abstract}

Keywords: Tribute; Biopolitics; Modernity; Contractualism; Social Development.

\footnotetext{
${ }^{1}$ Doutoranda do Programa de Pós-Graduação em Direito da Universidade Federal do Pará. Pesquisadora do Centro de Estudos sobre Instituições e Dispositivos Punitivos - CESIP. Analista Judiciário do TJPA. Pará (Brasil) E-mail: fsmalcher@gmail.com

${ }^{2}$ Docente permanente do PPG em Direito da UFPA. Doutor em Ciência Política/Políticas Públicas na Universidade da Sorbonne Nouvelle-Paris 3. Pesquisador/visitante do IPEA. Coordenador do CESIP. Pará (Brasil).
} 


\section{INTRODUÇÃ̃O}

O contratualismo de raízes hobbesiana justifica a origem do tributo a partir do seguinte paradoxo: era necessário limitar a liberdade dos indivíduos (sacrifício), visando aumentá-la (aposta filosófica), pois os meios dos tributos sustentam uma intrínseca relação com seus fins. Assim, na Modernidade, o tributo surge como expressão do liame social.

Gutmann (2005) defende como necessária a vinculação do direito à filosofia do tributo, consubstanciada na superação das distinções fiscais tradicionais entre diferentes tipos de imposições, e centrada em uma reflexão sobre a justiça substancial do tributo dentro de um contexto de renovação completa da noção de soberania. Defende o direito de filosofar sobre o tributo, em que pese os tributaristas se orgulharem de praticar uma ciência exata, e os filósofos, por seu turno, admitirem com muita reticência o tributo no campo de suas reflexões. Para ele:

É verdade que a complexidade e a tecnicidade da fiscalização têm do que objetar. Que estas características do direito tributário tenham sempre existido e que não sejam mais que a expressão da complexidade do direito como um todo, não resolve mais que metade do problema. E, se a fiscalidade sempre atraiu os sonhadores e os utopistas, a história, indiscutivelmente, discorda dos que confiam na simplicidade (GUTMANN, 2005, p. 29).

Ainda segundo Gutmann, em que pese a filosofia representar "o aguilhão do tributarista curioso" e "um tabu do direito tributário", a interrogação filosófica sobre o tributo se faz importante ante a necessidade de reflexão sobre as questões atinentes à justiça fiscal (2005, p.30): “Imperioso, pois, o estudo filosófico do tributo para além do senso jurídico, pois a justiça chama, para aqueles que a procuram, a filosofia".

O presente artigo não tem por escopo tecer uma análise filosófica sobre a justiça do tributo. Nossa intenção é apresentar o processo histórico de produção discursiva responsável pela consolidação da articulação acima mencionada, isto é, da concepção de tributo como expressão da vontade geral, nos exatos termos do contrato social.

Com vistas a esse fim, apresentamos, em um primeiro momento, uma síntese das principais ideias de Foucault e Agamben acerca da origem e consolidação do poder soberano na Modernidade, em oposição à teoria clássica da soberania. Sob a perspectiva teórica da filosofia crítica, remontamos à origem do tributo no pacto social, visando analisar os interesses e as ratios que o legitimaram no Estado Liberal. Nossa intenção foi fazer emergir os saberes sujeitados que permaneceram ocultos ao longo da construção teórica clássica do conceito de 
soberania consubstanciada no pacto social, e que teria justificado no século XIX a introdução da natureza humana e de seus direitos no discurso jurídico.

A partir da historicização do tributo no contexto biopolítico descrito por Foucault e Agamben, objetivamos demonstrar que a consolidação do tributo no Estado Moderno teve como fundamento o controle da vida por razões de economia política neoliberal, questão que merece ser enfrentada a fim de que possamos redimensionar o papel dos tributos na contemporaneidade e melhor compreender seus reflexos no desenvolvimento social.

\section{PODER, SOBERANIA E BIOPOLÍTICA}

Em seu estudo sobre a mecânica do poder e como este se relaciona com a governamentalidade - termo pelo qual denomina a nova arte de governar do Estado Moderno, cuja forma característica de exercício foi o biopoder ou biopolítica - o filósofo francês Michel Foucault desenvolveu concepção própria acerca da origem do estado soberano no século XIX e da prática governamental no exercício da soberania política. Por biopolítica, define como sendo a maneira como se procurou, desde o século XVIII, (2008, p-430): "racionalizar os problemas postos à prática governamental pelos fenômenos próprios de um conjunto de viventes constituídos em população: saúde, higiene, natalidade, longevidade, raças... [...]”.

Para Foucault (2010), a teoria clássica da soberania ou o modelo jurídico da soberania, centrado na ideia do contrato social pactuado entre Estado e cidadãos sob a forma de um vínculo jurídico, não se adapta a uma análise concreta da multiplicidade das relações de poder que se estabeleceram entre o soberano e seus súditos, a partir daquele século. Afirma que na tentativa de constituir um ciclo do sujeito ao sujeito, a teoria clássica da soberania encobriu, de um lado, como o sujeito, entendido como o indivíduo capaz de direitos e obrigações, pode e deve se tornar sujeito, mas desta vez, entendido como um elemento sujeitado em uma relação de poder. Pela visão foucaultiana, a teoria jurídica da soberania estaria pautada em um tríplice primitivismo: o sujeito que deve ser sujeitado, o da unidade do poder que decorre de uma lei geral e o da consequente legitimidade, que deve ser respeitada. Sujeito, unidade do poder e lei. Esses seriam os elementos da teoria clássica da soberania, conforme aquele autor.

Sob tal perspectiva, buscou desatrelar a análise do poder soberano dessa tríplice preliminar, com o escopo de fazer emergir as relações de dominação e seus operadores, no que elas têm de factual e efetivo (2010, p. 38): "portanto, não perguntar aos sujeitos como, por que, em nome de que direito eles podem aceitar deixar-se sujeitar, mas mostrar como são as relações 
de sujeição efetivas que fabricam sujeitos". Para analisarmos eficazmente a mecânica das relações de poder, não podemos tomá-lo como uma unidade global, mas sim, precisamos analisar sua atuação e os aparelhos nos quais se apoia, como o poder se constitui e a partir de que multiplicidade de sujeições. Trata-se de uma análise das estruturas de poder como estratégias globais e dos processos de subjetivação que o poder implica.

Nas palavras do autor:

[...] em vez da tríplice preliminar da lei, da unidade e do sujeito - que faz da soberania a fonte do poder e o fundamento das instituições -, eu acho que temos que adotar ponto de vista tríplice das técnicas, da heterogeneidade das técnicas e de seus efeitos de sujeição, que fazem dos procedimentos de dominação a trama efetiva das relações de poder e dos grandes aparelhos de poder. A fabricação dos sujeitos muito mais do que a gênese do soberano: aí está o tema geral. [...]. (FOUCAULT, 2010, p. 39).

Em sua análise do poder ou dos poderes, Foucault nos remete ainda a outra importante questão: como tal análise, de uma maneira ou de outra, é deduzida da economia. Ao ponto comum entre poder e economia, denomina de "economismo na teoria do poder". Ao formular tal questão, afirma:

Não quero de modo algum suprimir diferenças inumeráveis, gigantescas, mas, apesar e através dessas diferenças, parece-me que há um certo ponto em comum entre a concepção jurídica e, digamos, liberal do poder político [...] e também a concepção marxista [...]. Esse ponto comum seria aquilo que eu chamaria de 'economismo' na teoria do poder. (FOUCAULT, 2010, p. 13).

Mas alerta também para a necessidade de uma análise não econômica do poder, no sentido de que este não se dá, nem se troca, mas existe e se exerce mediante um ato. Primariamente, relação de força que existe e se exerce através de atos que manifestam tal relação. Nessa linha, o exercício do poder seria por meio da repressão e sua análise perpassaria, essencialmente, pelos mecanismos de repressão. Para Foucault (2010), o poder político tem como função a perpetuação da relação de força e de sua reinserção nas instituições, nas desigualdades econômicas, linguagens, inclusive, nos corpos dos indivíduos. Importante também seria o exame do modo como o poder atua, estende-se, modifica-se e desloca-se, motivado por fenômenos globais ou por razões econômicas. Segundo o autor, um outro tipo de análise do poder se faz importante: as produções ou edifícios ideológicos que o acompanham, pois o poder não se exerce sem formação, organização ou circulação de um saber. E o saber/poder também possui técnicas e táticas de dominação próprias.

É sob essa ótica que analisa a transição do Estado feudal para o liberal, entre os séculos XVII e XVIII, marcada pelo aparecimento de uma nova mecânica do poder, com procedimentos particulares e aparelhagem própria. Enquanto na sociedade feudal o poder exercia-se nos limites da relação entre soberano e súdito, com o advento do Estado Liberal, a nova mecânica de poder 
passa a incidir, primeiramente, sobre os corpos e seus atos, em um tipo de poder que visava extrair dos corpos tempo e trabalho. Descreve Foucault:

É um tipo de poder que pressupõe muito mais uma trama cerrada de coerções materiais do que a existência física de um soberano, e define uma nova economia de poder cujo princípio é o de que se deve ao mesmo tempo fazer que cresçam as forças sujeitadas e a força e a eficácia daquilo que as sujeita.

(FOUCAULT, 2010, p.31).

Esse tipo de poder, que não mais pôde ser transcrito nos termos da soberania, constituise em uma das grandes inovações da sociedade burguesa e em um dos instrumentos essenciais para a implantação do capitalismo industrial e da sociedade correlata àquele modo de produção. Tratava-se do poder disciplinar que recaiu sobre as sociedades modernas a partir do século XIX, exercendo-se através de mecanismos de dominação do corpo social, que os mantinha atado por uma trama cerrada de coerções disciplinares, de forma a garantir-lhe coesão. E o sistema jurídico incluindo o tributário, surge nesse cenário para legitimar os sistemas de coerções aplicados às sociedades modernas do século XIX. Nesse contexto, a organização de um código jurídico centrado na sociedade, permitiu sobrepor aos mecanismos de disciplina um sistema de direitos que, em verdade, mascarava tais procedimentos de dominação e disciplina, sob a forma de um estado soberano.

Segundo Foucault:

[...] Em outras palavras, os sistemas jurídicos, sejam as teorias, sejam os códigos, permitiram uma democratização da soberania, a implantação de um direito público articulado a partir da soberania coletiva, no mesmo momento, na medida em que e porque essa democratização da soberania se encontrava lastrada em profundidade pelos mecanismos de coerção disciplinar. De uma forma mais densa, poderíamos dizer o seguinte: uma vez que as coerções disciplinares deviam ao mesmo tempo exercerse como mecanismos de dominação e ser escondidas como exercício efetivo de poder, era preciso que fosse apresentada no aparelho jurídico e reativada, concluída, pelos códigos judiciários, a teoria da soberania. (Foucault, 2010, p. 32-33).

Ao final da Idade Média, vigorava o discurso da soberania, das raças, do enfrentamento das raças pelas nações e suas leis. Havia uma identificação implícita entre soberano e súdito, que se achavam unidos na unidade da cidade, da nação, do Estado. O povo estava subjugado ao seu monarca. Nos séculos XVII e XVIII, as técnicas de poder eram centradas no corpo individual, com procedimentos de separação, alinhamento, colocação em vigilância, punição e organização dos indivíduos em um campo de visibilidade. As técnicas visavam, entre outros, o incremento da força útil dos corpos por meio de treinamento e exercícios, da forma menos onerosa possível, mediante um sistema de vigilância, com racionalização e economia. Tratava-se de uma tecnologia disciplinar do trabalho, centrada na 
manipulação singular do corpo, com vistas a produzir efeitos individualizantes e à produção de corpos úteis e dóceis.

Contudo, a virada do século XVIII para o XIX foi marcada por um fenômeno fundamental naquela época, representado pela assunção da vida pelo poder, pelo controle do homem enquanto ser vivo, em uma espécie de estatização do biológico. Para melhor explicar tal fenômeno, o autor remete-se à teoria clássica da soberania, em que o direito de vida e de morte, ou seja, de deixar viver e o de fazer morrer (matar), respectivamente, pertencia ao soberano, como um direito de espada. Em contraposição àquela concepção do direito de soberania, no século XIX, vislumbra-se uma transformação no direito político, que passa a ser o de fazer viver e deixar morrer. Ocorre que a velha mecânica do poder da soberania, centrada na racionalidade jurídica e no controle disciplinar do indivíduo, torna-se inoperante para reger o corpo econômico da nova sociedade resultante da Revolução Industrial e em pleno processo de explosão demográfica, que demandava o controle em massa, a biorregulamentação estatal.

[...] Logo, depois de uma primeira tomada de poder sobre o corpo que se fez consoante o modo de individualização, temos uma segunda tomada de poder que, por sua vez, não é individualizante, mas que é massificante [...] que se faz em direção não do homem-corpo, mas do homem-espécie. Depois da anatomopolítica do corpo humano, instaurada no decorrer do século XVIII, vemos aparecer, no fim do mesmo século [...] uma 'biopolítica' da espécie humana. (FOUCAULT, 2010, p. 204).

A lógica que permeia as novas ações é a do capitalismo em plena ascensão. $O$ biopoder visa o controle das forças, das energias e de tudo aquilo que provoque a subtração e a redução da capacidade e do tempo de trabalho, como as doenças, as epidemias e endemias.

\begin{abstract}
Aquém, portanto, do grande poder absoluto, dramático, sombrio que era o poder da soberania, e que consistia em poder fazer morrer, eis que aparece agora, com essa tecnologia do biopoder, com essa tecnologia do poder sobre a 'população' enquanto tal, sobre o homem enquanto ser vivo, um poder contínuo, científico, que é o poder de 'fazer viver'. A soberania fazia morrer e deixava viver. E eis que agora aparece um poder que eu chamaria de regulamentação e que consiste, ao contrário, em fazer viver e em deixar morrer. (Foucault, 2010, p. 207).
\end{abstract}

Foucault (2009) nos mostra como, já nos séculos XVII-XVIII, a especificidade jurídica da cidade colocava um problema de difícil solução à massa de problemas decorrentes dos Estados administrativos. Destaca fenômenos como o crescimento do comércio, da demografia urbana, da subsistência e da circulação de bens, que clamava pela supressão das muralhas das cidades, em favor do intercâmbio econômico permanente destas, com seus entornos imediatos e distantes. Havia um encravamento espacial, jurídico, administrativo e econômico na cidade do século XVIII, que com o nascimento dos Estados modernos e a emergência do fenômeno da população, necessitava reorganizar a cidade em um espaço de circulação, com maximização da 
boa circulação. O princípio da liberdade de comércio e de circulação de riquezas, com raízes na doutrina fisiocrática, influenciou e promoveu uma série de mudanças nas técnicas de governo, em especial, no que o autor chama de dispositivos de segurança, em que, se utilizando de mecanismos de mercado, analisa-se o que acontece e calcula-se o que deve acontecer, em uma espécie de "racionalização do acaso e das probabilidades".

Em todo caso, para os mercantilistas do século XVII, a população já não aparece simplesmente como uma característica positiva que pode figurar nos emblemas do poder soberano, mas aparece no interior de uma dinâmica, ou melhor, não no interior, mas no princípio mesmo de uma dinâmica - da dinâmica do poder do Estado e do soberano. [...] A população está assim na base tanto da riqueza como do poderio do Estado é algo que só pode ocorrer, claro, se ela é enquadrada por todo um aparato regulamentar [...]. A população será considerada essencial e fundamentalmente força produtiva. (FOUCAULT, 2009, p. 90-91).

Em outras palavras, a nova ratio de Estado que se delineava naquele contexto, diante do problema população-riqueza e de gestão da relação recursos-população, utilizou-se da biopolítica para gerir essa população, termo criado para definir a nova governamentalidade ou a arte de governar característica dos Estados modernos. As práticas primeiras da biopolítica constituíram-se a partir da construção de um saber/poder sobre fenômenos aleatórios e imprevisíveis: natalidade, morbidade, capacidades biológicas e etc., eleitos campos de intervenção, em razão dos efeitos políticos e econômicos no plano coletivo. Foucault destaca três características elementares da biopolítica do século XVIII: 1) O aparecimento da noção de população, raciocinada como um problema político, científico, biológico e econômico. 2) A natureza coletiva e fortuita dos fenômenos que são alvo de intervenção deste poder. 3) Os mecanismos ou tecnologias peculiares de implantação da biopolítica, reguladores da população global, destinados à maximização de forças e à neutralização das incapacidades. De outro lado, o mercado - e juntamente com ele as suas leis naturais - emerge como o controlador dos corpos, e indivíduos são tratados como mercadorias, em uma vitória do utilitarismo. Refere o autor:

[...] qual o valor de utilidade do governo e de todas as ações do governo numa sociedade em que é a troca que determina o verdadeiro valor das coisas? [...] a punição aparece como devendo ser calculada em função, é claro, dos interesses da pessoa lesada, da reparação dos danos, etc. Doravante, porém, a punição deve arraigar-se apenas no jogo dos interesses dos outros, do seu meio, da sociedade, etc. Interessa punir? Que interesse há em punir? Que forma a punição deve ter para que seja interessante para a sociedade? Interessa supliciar ou o que interessa é reeducar? E reeducar como, até que ponto, etc., e quanto vai custar? A inserção desta película fenomenal do interesse constituindo a única esfera, ou antes, a única superfície de intervenção possível do governo - é isso que explica essas mutações que devem ser todas, como vocês veem, referidas a esse arranjo da razão governamental" (FOUCAULT, 2008, p. 63-64). 
De acordo com essa nova lógica de governo, consolidada a partir do século XIX, o mercado, que antes era lugar de justiça, passa a ser o lugar de veridição, isto é, do regime da verdade. E a noção de justiça deu lugar à verdade mercadológica. O mercado, a partir daí, passa a estabelecer como o Estado deve agir, na medida em que estabelecia o que era natural ou normal. Em suma, no século XVIII, o mercado era considerado o lugar de justiça. Cabia ao Estado definir o preço justo e regulamentar o sistema de trocas e de coerção, aplicado pelos senhores feudais. Todavia, no século XIX, com a ascensão de uma nova razão de Estado, baseada menos em princípios de Justiça do que em princípios econômicos e neoliberais, o Estado, de garantidor de direitos, passou a assegurar as regras naturais do mercado, como mantenedoras das relações de oferta e procura, de troca, de livre concorrência, etc. Mas Foucault ensina que ao contrário do liberalismo clássico, o neoliberalismo no contexto do Estado Moderno não teve como supedâneo o laissez-faire, e sim, surgiu como ideologia fundamentadora da nova arte de governar, que tinha na população o objeto de sua intervenção. O Estado neoliberal é funcional ao mercado e o neoliberalismo visava dirigir os indivíduos pelo exercício da liberdade. Nas palavras de Domínguez Ugá:

\begin{abstract}
As ideias de mercado, competição, concorrência são trazidas para o centro da ação governamental enquanto modelo a ser seguido e implementado. Assim, na verdade, o neoliberalismo não é um simples um retorno da crença no livre funcionamento do mercado, mas uma nova mobilização (inclusive do próprio Estado) cujo objetivo é fazer com que a ideia de mercado se torne possível. Para tanto, a ação governamental passa a intervir sobre a própria sociedade com a tarefa de tornar possível o funcionamento dos mecanismos concorrenciais próprios do mercado. (DOMÍNGUEZ UGÁ, 2008, p. 58).
\end{abstract}

Ainda segundo aquela autora:

Deste modo, o que se procura com isso é a obtenção de uma sociedade submetida à dinâmica concorrencial, uma generalização da forma "empresa" no interior do corpo e do tecido social, tendo a concorrência como fundamento. "O homo economicus que se quer reconstituir não é o homem da troca, não é o homem consumidor, mas sim o homem empresarial" (ibidem, p. 152). Trata-se de inserir no tecido social a lógica da diferenciação social, dividindo-o e multiplicando-o em indivíduos a partir do modelo "empresa", ou seja, enfatizando seu lado competitivo e empreendedor como novas necessidades. (DOMÍNGUEZ UGÁ, 2008, p. 59).

Em suma, tais autores chamam atenção para a substituição, já no século XVIII, da razão de Estado representada pelo Direito - a racionalidade jurídico-dedutiva - calcada no pacto social, para a ratio de Estado mínimo, fundamentada na economia política, mais precisamente no neoliberalismo econômico, que foi o princípio da limitação interna dos estados liberais em ascensão. De acordo com Foucault (2008), as duas racionalidades implicam em duas concepções da lei. Na razão de Estado jurídico-dedutiva, a lei é concebida como expressão da 
vontade do povo, de uma vontade coletiva, manifestada pela parte de direitos que os indivíduos aceitaram ceder, e a parte que desejaram reservar. Na outra problemática, a ratio utilitarista, a lei foi concebida como efeito de uma transação, em que, de um lado, tem-se a esfera de intervenção do poder público, e de outro, a esfera de independência dos indivíduos. Temos, destarte, duas concepções de liberdade: uma jurídica, em que todo individuo detém certa liberdade da qual cederá ou não certa parte; e a outra que concebe a liberdade como a independência dos governados em relação aos governantes (Foucault, 2008, p-58): "É essa ambiguidade que caracteriza, digamos, o liberalismo europeu do século XIX e também do século XX”.

É sob tal prisma que, nesse trabalho, propomos analisar o tributo, concebido pela dogmática jurídica como a expressão da liberdade e do exercício de direitos fundamentais, nos termos do contrato social, mas que, conforme problematizamos, o tributo, desde a sua origem, também esteve orientado por razões de biopolítica estatal, que visava o controle da vida por razões de economia e de manutenção do poder estatal.

\section{O PARADOXO DA SOBERANIA: A VIOLÊNCIA QUE CRIA E SUSPENDE O DIREITO}

Discípulo de Foucault, o filósofo italiano Giorgio Agamben (2010) também critica a concepção tradicional acerca da origem do poder soberano, centrada exclusivamente no modelo jurídico clássico, alertando para a necessidade de repensá-la sob o contexto da nova razão de Estado delineada a partir do século XIX, cujo exercício foi o biopoder. Para ilustrar seu pensamento, descreve uma estrutura lógica e topológica da soberania a partir de noções elementares como zoé e bíos, palavras de origem grega que traduzem o sentido da vida. Enquanto zoé significa o simples viver, a vida nua ou natural que coloca homens, animais e deuses no mesmo patamar de seres viventes; bíos, por seu turno, traduz a vida qualificada, a forma ou maneira de viver particular a cada um. Juntas, expressam o conflito entre a vida natural versus a vida política.

Com base nesses dois termos, Agamben (2010) analisa como na Idade Clássica, operou-se a politização da vida natural a partir do seu ingresso na pólis, convertendo-se em zoé politiké, marcada pelo oikonómos, em que o simples viver opõe-se à vida politicamente qualificada, em vista do bem viver. O diálogo com Foucault estabelece-se no momento em que, na Idade Moderna, a vida natural passa a ser calculada pelo poder estatal, a partir da nova 
governamentalidade que ali se delineava, cujo exercício era o biopoder. Nesse sentido, a politização da vida nua a partir do ingresso da zoé na esfera da pólis, constitui o evento decisivo e fundador da modernidade, que rompe radicalmente com o pensamento político-filosófico clássico.

A partir da relação entre vida nua e política, Agamben desenvolve o seu próprio raciocínio sobre o poder político na atualidade, que segundo ele, permeia as categorias opostas e aparentemente distantes do absolutismo/democracia; direita/esquerda; privado/público; fazendo-as conviver no que chama de "zona de indiscernibilidade", ou, "zona de indistinção". Chama atenção para a existência de um ponto de interseção entre o modelo jurídicoinstitucional e o modelo biopolítico do poder, a fim de delimitar a zona de indiferenciação entre as técnicas disciplinares de individualização e as totalizantes. Em suas palavras (2010, p. 14): “a implicação da vida nua na esfera política constitui o núcleo originário - ainda que encoberto - do poder soberano. Pode-se dizer, aliás, que a produção de um corpo biopolítico seja a contribuição original do poder soberano".

Propõe uma análise da soberania a partir do vínculo que une o poder político à vida nua. Segundo ele, a política ocidental, ao transformar a vida natural em política, constitui-se a partir da exclusão daquela, na mesma medida em que, ao assumir o controle sobre a vida, a inclui.

[...] é necessário, antes de mais, perguntar-se por que a política ocidental se constitui primeiramente através de uma exclusão (que é, na mesma medida, uma implicação) da vida nua. Qual é a relação entre política e vida, se esta se apresenta como aquilo que deve ser incluído através de uma exclusão? (AGAMBEN, 2010, p. 14).

A vida política é o lugar em que o viver deve se transformar em bem viver (forma qualificada da vida). Enquanto na vida natural o homem possui voz, na política, ele faz uso da linguagem. E foi sobre a politização da vida nua que se fundou a pólis. Para melhor ilustrar a função essencial que a vida nua assumiu na política moderna, utiliza-se da figura do homo sacer, - outro elemento central em sua teoria - e da relação deste com o estado de exceção soberano. Figura enigmática oriunda do direito romano arcaico, o homo sacer é a representação do ser vivente situado à margem da ordem jurídica. Como a lei a ele não se aplica, sua vida, embora insacrificável, é plenamente matável, visto que não protegida ou tutelada pela norma. Como o Direito a ele não se aplicava, não podia receber uma pena capital, nem ser condenado à morte. Todavia, caso viesse a ser morto, o fato não configuraria homicídio, pois sua existência não constituía um bem jurídico, não havendo, por consequência, imputabilidade de crime ao agente. Tratava-se de uma época em que o direito religioso e o penal não se distinguiam. A vida do 
homo sacer era propriedade dos deuses e sua condenação à morte implicava em um sacrifício à divindade.

A partir da estreita relação entre vida nua e política, Agamben (2010) delimita como a exclusão, representada pelo homo sacer, preso à sua condição de mero ser vivente, relacionase com politização da vida, ou, com a inclusão desta pelo estado soberano, formando uma zona de irredutível indistinção entre o biológico e o político, o fato e o direito, o externo e o interno. Para ilustrar a íntima relação entre a vida natural e a vida politizada, exclusão e inclusão na ordem política, analisa a lógica do poder soberano sob o que chama de paradoxo da soberania de Carl Schmitt, em que o soberano está, ao mesmo tempo, dentro e fora do ordenamento jurídico, em virtude do poder a ele conferido de decretar o estado de exceção, isto é, de suspender a validade do ordenamento. O soberano, tendo o poder legal de suspender a validade da lei, coloca-se legalmente fora da lei, e a soberania constitui-se no limite do ordenamento jurídico, no seu princípio e fim. Tal decisão cabe ao soberano, investido no monopólio desse poder. Segundo o autor:

O caso de exceção torna evidente do modo mais claro a essência da autoridade estatal. Aqui a decisão se distingue da norma jurídica e (para formular um paradoxo) a autoridade demonstra que não necessita do direito para criar o direito... A exceção [...] ela não só confirma a regra: a regra mesma vive só da exceção... [...]. (AGAMBEN, 2010, p. 23).

Em outras palavras, o caos, representado pela vida natural precede a ordem, esta por sua vez, representada pela vida política. O zoé, o mero viver, possui natureza pré-jurídica. $\mathrm{O}$ direito origina-se no caos, a partir da decisão do soberano que institui a ordem. Mas por ser soberano, este também tem o poder de decidir sobre a suspensão da vigência da ordem. Agamben (2010) observa a relação de exclusão inclusiva decorrente do poder soberano e do estado de exceção: ao instituir a ordem, o soberano capta a vida nua através da politização do ser vivente. O homem é incluído na ordem pela exclusão do seu ser biológico. Sob a categoria jurídica do estado de exceção, que consiste no poder soberano de dispor sobre a vida e de suspender a ordem, Agamben critica o conceito jurídico de soberania, construído sob o princípio de que aquela pertence indissociavelmente à ordem da lei, concepção inseparável da noção de democracia e de Estado de Direito.

Necessário, pois, confrontá-la com o parodoxo da soberania por ele exposto, que acaba por impelir o conceito jurídico ao extremo. Para aquele autor, há um princípio oculto que orienta a definição de poder soberano que, longe de pautar-se unicamente na lei, é, na verdade, um princípio que conjuga violência e direito, indistintamente (AGAMBEN, 2010, p. 38): “[...] o 
soberano é o ponto de indiferença entre violência e direito, o limiar em que a violência traspassa em direito e o direito em violência".

Aborda, assim, a função da violência na criação jurídica, afirmando que a soberania é constituída pela coincidência entre direito e violência, na medida em que esta põe e conserva o direito. A violência como meio e o direito como fim por ela perseguido. Há, portanto, um nexo essencial entre vida nua e violência jurídica, na constituição do poder soberano. Tal nexo é irredutível e os une em uma dialética circular, em que a força criadora é mantida pela violência criada, até que novas forças se emerjam e deponham o direito posto, criando um novo.

O paradoxo da soberania mostra-se claro no problema do poder constituinte em relação ao poder constituído. Enquanto os poderes constituídos existem no Estado, amoldados a uma ordem constitucional pré-estabelecida; o constituinte posiciona-se fora do Estado, a quem nada deve. De um lado, a violência que põe o direito; de outro, a que o conserva. Para Agamben (2010), a relação exprime o paradoxo da soberania pelo fato de o poder constituinte pressupor e representar o estado de natureza. Ao constituir-se, o poder soberano transforma-se em poder constituído, mantendo uma relação de exceção com o estado de natureza. Estabelece, pois, uma relação entre a figura do homo sacer e a categoria jurídica da exceção soberana. Ao homo sacer era destinado o "bando" - outro termo central em sua teoria -, que por sua vez, expressa o “abando-no", o banimento do indivíduo, como forma de consagração da divindade.

“O que é, então, a vida do homo sacer, se ela se situa no cruzamento entre uma matabilidade e uma insacrificabilidade, fora tanto do direito humano quanto daquele divino?". (AGAMBEM, 2010, p. 76).

O bando significa o poder conferido ao soberano de banir, de excluir, ou, nas palavras de Giacoia Junior:

Trata-se da figura do excluído, do pária cuja morte não constitui homicídio, ao qual o ordenamento que o penaliza se impõe sob a forma da suspensão de seus efeitos e da prerrogativa de sua invocação. É de se notar a homologia estrutural entre bando (Bann) exceção (exceptio, ex capere, "capturar fora"), paradoxo sobre o qual se constrói grande parte da argumentação de Agamben. (GIACOIA JUNIOR, 2008).

O autor ressalta o tabu que envolve ambivalência do sacro, em que a noção de santidade e de impuridade se tocam. O termo latino sacer denota santo e maldito. O homo sacer se situa do lado de fora da jurisdição humana. Nas palavras de Agamben:

Assim como, na exceção soberana, a lei se aplica de fato ao caso excepcional desaplicando-se, retirando-se deste, do mesmo modo o homo sacer pertence ao Deus na forma da insacrificabilidade e é incluído na comunidade na forma da matabilidade. A vida insacrificável e, todavia, matável, é a vida sacra. (2010, p. 84). 
O que o autor quer demonstrar é a conexão entre as estruturas da soberania e da sacratio (AGAMBEN, 2010, p. 84): “[...] o homo sacer apresentaria a figura originária da vida presa no bando soberano e conservaria a memória da exclusão originária através da qual se constituiu a dimensão política". Assim, o espaço político da soberania foi construído em uma zona de indiscernibilidade entre sacrifício e homicídio. Na esfera soberana, o soberano pode matar sem cometer homicídio. A vida capturada naquela esfera é, ao mesmo tempo, matável e insacrificável. Para o autor, a estrutura política originária da soberania tem lugar nessa zona que precede a distinção entre sacro e profano, religioso e jurídico. A vida nua ou sacra é a que constitui o poder soberano, através da sua politização. Mas essa mesma vida é capturada pela exceção soberana, que dela pode dispor. Refere que:

A sacralidade da vida, que se desejaria hoje fazer valer contra o poder soberano como um direito humano, em todos os sentidos, fundamental, exprime, ao contrário, desde sua origem, a sujeição da vida a um poder de morte, a sua irreparável exposição na relação de abandono. (Agamben, 2010, p. 85).

Há, portanto, uma analogia estrutural entre exceção soberana e sacratio, em que a vida nua ingressa na ordem jurídico-política, em uma exclusão-inclusiva. O sacer marca a formulação política original da imposição do vínculo soberano.

Nos dois limites extremos do ordenamento, soberano e homo sacer representam duas
figuras simétricas, que têm a mesma estrutura e são correlatas, no sentido de que
soberano é aquele em relação ao qual todos os homens são potencialmente homines
sacri e homo sacer é aquele em relação ao qual todos os homens agem como
soberanos. (Agamben, 2010, p. 86).

Coloca em xeque, assim, a teoria do contrato social, enquanto pacto fundador do Estado. Para o autor, o vínculo originário do Estado fundou-se na forma de dissolução ou exceção, na qual a vida humana é, ao mesmo tempo, capturada e excluída, politizada através do abandono a um poder incondicionado de morte.

Mais originário que o vínculo da norma positiva ou do pacto social é o vínculo soberano, que é, porém, na verdade somente uma dissolução; e aquilo que esta dissolução implica e produz - a vida nua, que habita a terra de ninguém entre a casa e a cidade - é, do ponto de vista da soberania, o elemento político originário. (Agamben, 2010, p. 91).

O pensamento de Agamben é contrário a tudo o que a modernidade sedimentou em relação à representação social e política do indivíduo no pacto social, em termos de direitos e de livre arbítrio, do ponto de vista da soberania, pois, para o autor, política é apenas a vida nua.

Por isto, em Hobbes, o fundamento do poder soberano não deve ser buscado na cessão livre, da parte dos súditos, do seu direito natural, mas, sobretudo, na conservação, da parte do soberano, de seu direito natural de fazer qualquer coisa em relação a qualquer 
um, que se apresenta então como direito de punir. [...]. A violência soberana não é, na verdade, fundada sobre um pacto, mas sobre a inclusão exclusiva da vida nua no Estado. (Agamben, 2010, p. 106).

Atenta para a necessidade de releitura do mito da fundação do estado moderno, de Hobbes a Rousseau. O estado de natureza é o estado de exceção, e o ordenamento nasce em virtude da decisão soberana que, por sua vez, relaciona-se com a vida, e não, com a livre vontade dos cidadãos. A vida é o elemento político originário da política, mas também, substancial, na medida em que une a vida nua ao poder soberano.

É preciso dispensar sem reservas todas as representações do ato político originário como um contrato ou uma convenção, que assinalaria de modo pontual e definido a passagem da natureza ao Estado. [...]. Este mal-entendido do mitologema hobbesiano em termos de contrato em vez de bando, condenou a democracia à impotência toda vez que se tratava de enfrentar o problema do poder soberano e, ao mesmo tempo, tornou-a constitutivamente incapaz de pensar verdadeiramente, na modernidade, uma política não estatal. (Agamben, 2010, p. 109).

É sob tal perspectiva que o contrato social e a metáfora do Leviatã - enquanto corpo representativo de todos os corpos dos indivíduos - devem ser repensados: a partir do estreito liame entre soberania e vida nua (AGAMBEN, 2010, p. 122): "São os corpos absolutamente matáveis dos súditos que formam o novo corpo político do Ocidente".

Tendo por escopo as concepções de Foucault e Agamben acerca da origem e da lógica na qual se fundamentou o Estado Soberano, e da ascensão da nova razão de Estado a partir do século XIX, centrada no biopoder, no controle da vida, pretende-se, a partir de agora, articulálas à análise da História do Tributo, com vistas a demonstrar que o discurso jurídico de positivação do tributo, calcado no contrato social e no exercício da liberdade e da garantia de direitos naturais pelo Leviatã, também foi motivado por razões de controle social e de economia política, o que se verifica até hoje nas sociedades contemporâneas.

\section{O FUNDAMENTO BIOPOLÍTICO DOS TRIBUTOS:}

Ives Gandra da Silva Martins, em sua análise histórica dos tributos, afirma que:

[...] a história do tributo revela que quase sempre foi utilizado como instrumento de força e de poder dos governantes, na busca de conquistas, guerras, espaços e em benefício próprio - inclusive na eliminação de seus inimigos [...] a história do tributo é apenas a história do poder e o contribuinte, seu pagador, mero peão, num jogo de xadrez, em que pode ser manipulado, confiscado, espoliado de seus recursos, de acordo com a vontade dos dirigentes do poder. (MARTINS, 2005, p. 90).

Desde os primórdios, o tributo esteve na essência das sociedades primitivas. O trabalho constituía o tributo em espécie da época, representado, por exemplo, pelo esforço em conjunto 
na defesa da aldeia contra o ataque de animais ou de outras comunidades. Em momento posterior, quando as tribos sedentárias suplantaram as tribos nômades e o crescimento populacional separou os indivíduos em classes dirigentes e subordinadas, os detentores do poder assumiram o domínio sobre o direito natural, sujeitando a classe servil a produzir recursos para o sustento dos dominantes, em especial, para custear as guerras entre comunidades vizinhas. Nas palavras de Martins:

O certo é que a tributação passou, neste estágio da civilização, não mais a representar algo justo e em prol da comunidade - como no início, quando era paga por todos em espécie - mas algo injusto em que a comunidade levava muito ao poder e pouco do Poder recebia. (Martins, 2005, p. 86).

As guerras de conquista eram feitas sempre à custa dos tributos, por sua vez, retirados em espécie dos dominados: trabalho depois moeda, serviços ou produtos, na medida das ambições de conquista e no domínio sobre outros povos, com vistas ao aumento das riquezas. $\mathrm{Na}$ Antiguidade clássica, à medida que as cidades-estados transformaram-se em impérios, Galvêas (2007) descreve a estrutura do Estado organizada da seguinte forma: de um lado, o soberano, ou rei ou imperador, e seu respectivo exército, representando o Poder e o Estado; e de outro, os milhares de trabalhadores dos quais eram retirados os tributos devidos ao governante.

Ao lado dessa estrutura, a mecânica de poder estatal também se realizava por meio das chamadas guerras de conquista entre os estados. Assim, os mesmos exércitos que defendiam as suas cidades, invadiam e saqueavam outras cidades, com o fito de roubar riquezas, aprisionar habitantes como escravos e impor, aos que permaneciam no campo, o pagamento de tributos (GALVÊAS, 2007, p.317): “Assim sendo, tributo e Estado surgem ao mesmo tempo, com o povo - cidadão e escravos - de um lado, e os governantes, de outro lado, com seus exércitos”. Segundo Martins (2005), o povo, na Antiguidade, era pagador de tributos in natura, ou, em espécie, sem qualquer esperança de contrapartida por parte do Estado, que o manipulava como instrumento de domínio interno e externo.

Na Idade Média, a estrutura de poder característica da Antiguidade pulverizou-se em centenas de senhores feudais. Estes, legítimos proprietários das terras e dos instrumentos de produção, construíram pequenas cidades no interior de seus castelos, cercadas de muralhas. No feudalismo, aos servos que trabalhavam no cultivo das terras de seus senhores, cabia a obrigação de lhes pagar tributos, o que se configurava pela entrega ao senhorio de parte de sua produção, ou, o trabalho gratuito (escravo) nas terras do seu respectivo senhor. 
Em momento seguinte, o regime feudal, baseado na terra e na cobrança de tributos sobre a produção agrícola, é substituído pelo mercantilismo, por sua vez, apoiado na troca de mercadorias e no insipiente comércio que se desenvolve nas grandes cidades, principalmente, entre países, estimulado pelo desenvolvimento das companhias marítimas e pela fase das grandes navegações. Surgem, pois, os tributos sobre transações comerciais, como as tarifas aduaneiras e o imposto sobre importações.

Pela breve análise histórica do tributo, constata-se que este sempre existiu, mas conforme observa Galvêas (2007), ao longo do tempo, passou por inúmeras transformações, como se depreende da transição entre o regime tributário da antiguidade para o feudalismo, deste ao mercantilismo, e, finalmente, o regime instaurado pela Revolução Industrial. Deflagrado e consolidado o processo industrial, o sistema tributário passa por novas transformações, marcadas pela criação de impostos sobre a produção industrial, sobre o consumo e sobre o lucro e a renda recebida pelos proprietários. De tributos em espécie e sobre bens, passou-se à tributação em moeda.

Contudo, o marco na história dos tributos ocorre a partir da aproximação entre tributo e democracia, ou, tributo e representatividade, marcada pelo contratualismo. Conforme visto, durante muito tempo, não havia preocupação com a legalidade do tributo e o soberano manipulava-o de forma discricionária, conforme os seus interesses, em um verdadeiro absolutismo tributário. Mas, de acordo com Campos (2007), é no Estado representativo que o tributo se fixa como um instrumento de receita, em que os representantes do povo, em nome da vontade geral, escolhem os tributos a ser pagos e o tributo passa a ser uma manifestação da soberania do Estado, com finalidades fiscais e extrafiscais. Para Torres (2007), no Estado liberal de direito, o tributo surge a partir da eliminação dos privilégios da nobreza e do clero.

Em suas palavras:

O Estado Liberal Clássico, ou Estado Guarda-Noturno, necessita de receita tributária para atender às suas finalidades essenciais, menos escassas que anteriormente. $\mathrm{O}$ conceito jurídico de imposto se cristaliza a partir de algumas ideias fundamentais: a liberdade do cidadão, a legalidade estrita, a destinação pública do ingresso e a igualdade (Torres, 2007, p. 37).

No contexto do liberalismo e do contrato social, a liberdade é o fundamento maior do imposto, e este surge no espaço aberto pelas liberdades fundamentais, logo, limitado por essas liberdades (TORRES, 2007, p. 37-38): “O Estado, de origem contratual, constitui-se no espaço aberto pelo acordo entre as vontades individuais; nesse espaço constitui-se também o imposto, que tem por objetivo a garantia das liberdades fundamentais". 
Na Modernidade, foi com supedâneo no contrato social - em que o cidadão abria mão de uma parcela de sua liberdade para que o Estado lhe assegurasse o exercício de direitos fundamentais - que se fundamentou a imposição do tributo, que tinha por escopo, justamente, financiar as atividades estatais garantidoras da liberdade. Supostamente, foi em nome da liberdade, conservada no pacto social, que o tributo se consolida como expressão da vontade geral do povo soberano. Todavia, conforme visto pelas formulações de Foucault e Agamben, ambos advertem-nos para a necessidade de reformular a teoria clássica da soberania, a fim de melhor pensarmos a origem das relações de poder entre soberano e povo estabelecidas na Modernidade e originárias do Direito Liberal, e de como aquelas refletem na atualidade, em especial, sobre a efetivação dos direitos do homem.

Viu-se que, juntamente com o advento do Estado Moderno, delineou-se uma nova mecânica de exercício de poder, uma nova governamentalidade, que sob a vestimenta do biopoder, visava atender às exigências da sociedade industrial-capitalista em plena ascensão, por meio do cálculo e do controle dos fenômenos decorrentes da nova forma de organização social: a população. Foucault denominou de biopolítica à implicação da vida natural do homem nos mecanismos e nos cálculos do poder, e aos processos de subjetivação, na passagem do mundo antigo para o moderno, que levou o indivíduo a constituir-se como sujeito, na mesma medida em que se vinculava a um poder de controle externo, capaz de fazer viver e de deixar morrer. E é sob o contexto biopolítico que se pretende analisar o tributo.

Historicamente concebidos como instrumentos para o exercício de liberdades públicas, os tributos, constitucionalmente positivados, têm no discurso que os legitima a característica de constituírem-se como limites ao amplo e arbitrário exercício do poder estatal. Todavia, a filosofia política tradicional e a racionalidade jurídica ocidental mostraram-se incapazes de explicar as atrocidades cometidas contra os direitos naturais ou fundamentais ao longo da história, bem como, a crise de efetividade que enfrentam na contemporaneidade, com base, exclusivamente, no fundamento da razão de estado clássica ou no modelo jurídico da soberania.

As reflexões de Foucault sobre a soberania estatal e, mais recentemente, de Agamben, remetem-nos à necessidade de repensar o fundamento do tributo a partir de uma outra ratio, que não a consolidada pela dogmática jurídica, e sim, por uma razão de economia política, que serviu como supedâneo para a nova arte de governar dos estados nacionais. É com base em tal entendimento que se almeja empreender uma reflexão biopolítica crítica acerca dos tributos, em oposição à concepção do contratualismo clássico, alertando para a urgência de raciociná-los 
também como manifestações do poder soberano no que concerne ao poder de capturar e controlar a vida, a fim de atender à lógica do biopoder e às exigências de mercado.

Questionamos que interesses estavam por detrás da regulamentação da tributação no século XIX: assegurar a fruição da liberdade pelos homens - conforme preleciona o contratualismo -, ou o controle da população emergente, ante a explosão do capitalismo, motivado por razões de interesse puramente, econômico? Importante, pois, a análise do tributo como um complexo paradoxal, que por vezes esteve atrelado à ideia de liberdade e, em outras, ao controle e à dominação social.

De acordo com a teoria clássica da soberania sustentada pelo discurso jurídico, no seio do contrato social, a liberdade e a propriedade são direitos naturais, que, em tese, não admitem restrições. Para assegurar o exercício pacífico de tais direitos, necessária a presença do Leviatã como garantidor da ordem, daí a ideia do tributo como liberdade. A estrutura bipolar do tributo, em que o fomento à liberdade ocorre por meio do constrangimento à liberdade, revela-nos o paradoxo da soberania descrito por Agamben (2010), em que o soberano, ao mesmo tempo em que institui e assegura a ordem, tem o poder de suspender a ordem ou dela dispor. Isso explicaria porque o tributo, concebido como meio de desenvolvimento e justiça social, não tem logrado êxito em sociedades como a nossa, por exemplo, no tocante à função de promover o desenvolvimento humano e social. É que o controle da vida e a manutenção do poder estatal, desde a gênese do Estado soberano, estiveram por detrás da normatização dos tributos no século XIX, o que precisa ser compreendido a fim de que possamos, também, entender o papel da tributação no século atual, enquanto atividade essencial para manutenção do poder soberano.

Na visão de Martins, para efeitos de domínio e poder, o tributo constitui-se no mais importante elemento, refletindo em cada uma delas. Afirma o autor:

\footnotetext{
O poder só se mantem por força do tributo, que, certamente, é relevantíssimo para que os governantes, que dele usufruem, alimentem seus planos presentes e futuros de governo. Mesmo quando prestam serviços públicos, o retorno em serviços à comunidade é menor do que deveria ser, pois seu ideal maior é o poder pelo poder. (Martins, 2007, p. 6).
}

A origem biopolítica do tributo no Estado Moderno corrobora a sua função histórica de instrumento de manobra política para manutenção do poder soberano. Para Martins (2007), isso explicaria porque o tributo, em seu efeito colateral, é também utilizado em nível mínimo de serviços públicos no Estado Moderno, para que os produtores de riqueza e o povo não cheguem a explodir, como já ocorreu no curso da História. Segundo aquele autor, o tributo se mantém como uma norma de rejeição social, destinado à manutenção dos detentores do poder, 
e em grande instrumento de exercício do poder por parte destes, com apenas alguns efeitos colaterais positivos em prol do povo, quando há algum retorno em serviços públicos. O controle social e a manutenção do poder teriam sido as funções precípuas do tributo no Estado moderno, o que permanece em vigor na atualidade.

\footnotetext{
Não sem razão, no direito administrativo brasileiro - hoje o país é um Estado democrático de Direito - o governante é denominado 'administrador' e o cidadão, a quem todo o poder deveria ser outorgado, apenas 'administrado'. Nada obstante termos uma Constituição cidadão, o 'ato do príncipe' é aquele em que se lastreia a busca do interesse público - quase sempre apenas dos detentores do poder [...]. E os 'atos do príncipe', que se justificam por si só, na administração pública, são sempre suportados pelos tributos dos contribuintes. (Martins, 2007, p. 90-91).
}

Mas, para aquele autor, é possível que, no futuro, o tributo venha a ter uma função social maior, que deverá ocorrer não por mudança no perfil dos governantes, mas pela força da necessidade de sobrevivência.

[...] o século XX foi o século do reconhecimento dos direitos; o século XXI poderá ser aquele da efetividade dos mesmos, quando os contribuintes possivelmente poderão ter um tratamento mais digno por parte dos controladores e uma carga tributária mais justa e mais adequada à prestação de serviços públicos, entre os quais o de ações sociais efetivas. Até lá, mantenho a minha teoria de que o tributo é apenas um fantástico instrumento de domínio, por parte dos governantes. (Martins, 2007, p.6-7).

Com base em tal reflexão, concluímos que, desde a origem do Estado soberano, os detentores do poder manobram o tributo com o fito de manter o poder, a desigualdade e o controle da vida, em detrimento da justiça fiscal, social e do desenvolvimento econômico.

\section{CONSIDERAÇÕES FINAIS}

Sob a perspectiva da biopolítica de Foucault e Agamben, buscamos analisar as razões que fundamentaram a regulamentação do tributo na gênese do Estado Liberal. Com o nascimento do Estado Moderno e da prática da biopolítica, a vida humana foi capturada pelo poder soberano elevando-a ao status de categoria política, com vistas à manutenção da potência do Estado capitalista em ascensão. O exercício do biopoder objetivava o controle dos corpos e das condutas, por meio de técnicas disciplinantes e totalizantes, que visavam à produção de corpos dóceis e úteis ao capitalismo. Foi nesse contexto que o tributo no século XIX emergiu para também atender à lógica do biopoder estatal, fato que não pode ser ignorado para uma compreensão abrangente dos atuais reflexos da tributação no desenvolvimento humano e social.

Pela visão dos autores aqui mencionados associada à História do Tributo, concluímos que o discurso do contrato social - nos moldes da teoria clássica da soberania - legitimador do 
tributo como instrumento de defesa e exercício das liberdades públicas, em sua história, constituiu-se em uma das ferramentas do biopoder para potencializar o gerenciamento sobre a vida da população, não somente no aspecto biológico, como também subjetivo, abrangendo as liberdades em geral. Em outras palavras, a inclusão da vida nua na esfera política foi uma das formas de inserção da vida nos cálculos do poder soberano. Mas sob a lógica do biopoder, o domínio da vida mascara-se sob a forma de proteção, de cuidado, discurso este que foi amparado e legitimado pelo Direito e o é até os dias de hoje.

Assim, os tributos, que pela teoria clássica da soberania foram concebidos como manifestações do vínculo político-jurídico entre Estado e cidadãos e da submissão e limite daquele poder à soberania popular, em verdade, carregam desde a sua origem a função de possibilitar os meios de manipulação, controle, prolongamento e até de extinção da vida pelo soberano. De outro lado, os estudiosos da história, filosofia e sociologia do tributo nos mostram como este, desde os primórdios da humanidade, foi e continua sendo o elemento mais relevante para o exercício do poder político-estatal, e quem governa é quem determina o destino de um povo.

Nas palavras de Ives Gandra Martins:

\begin{abstract}
No mundo moderno [...] a maior parcela do povo continua sendo a das pessoas que, na realidade, tem direitos reduzidos. Embora seus direitos sejam decantados, nas leis e constituições, o povo está fadado a servir e a obedecer e a prestar-se, como massa de manobra, para os que ambicionam o poder e procuram iludi-lo com suas promessas, raramente cumpridas. (Martins, 2007, p. 5).
\end{abstract}

Em linhas gerais, grande parte dos tributos que a sociedade paga ao Poder Público, na realidade, não tem beneficiado seus legítimos destinatários, mas exclusivamente, os detentores do poder: "razão pela qual Poder e Tributo são irmãos siameses inseparáveis, sustentados pela classe inferior e dominada, que é o povo e a sociedade”. (Martins, 2005, p.51-52).

O presente artigo não se prestou a refutar a concepção de tributo enquanto instrumento de justiça fiscal e social e de garantia do exercício de liberdades no pacto social. Mas através da genealogia da origem e consolidação do Estado soberano na modernidade, buscamos analisar o fundamento do tributo sob outra lógica, diversa da sustentada pela teoria tradicional da soberania. O objetivo foi ampliar o entendimento acerca da situação predominante em nossa sociedade, em que ainda não se atribuiu a importância devida à composição do tributo e sua destinação ao que retorna à sociedade em serviços e em desenvolvimento, vez que a função precípua do tributo continua sendo a de manutenção do poder, através da manipulação e/ou controle da vida. 


\section{REFERÊNCIAS BIBLIOGRÁFICAS:}

AGAMBEN, Giorgio. Homo Sacer - O poder soberano e a vida nua I, Profanações. Belo Horizonte: Ed. UFMG, 2010.

FERRAZ, Roberto. GUTMANN, Daniel. Princípios e Limites da Tributação. São Paulo: Ed. Quartier Latin, 2005.

FOUCAULT, Michel. Em Defesa da Sociedade. São Paulo: Ed. Martins Fontes, 2010.

FOUCAUlT, Michel. Segurança, Território, População. São Paulo: Ed; Martins Fontes, 2009.

FOUCAULT, Michel. Nascimento da Biopolítica. São Paulo: Ed. Martins Fontes, 2004.

GIACOIA JUNIOR, Oswaldo. Sobre direitos humanos na era da bio-política. Kriterion, Belo Horizonte, v. 49, n. 118, Dec. 2008. Disponível em: <http://www.scielo.br/scielo.php?script=sci_arttext\&pid=S0100512X2008000200002\&ln $\mathrm{g}=\mathrm{en} \& \mathrm{nrm}=\mathrm{iso}>$. Acesso em 22 Jul. 2013.

MARTINS, Ives Gandra da Silva. Uma Teoria do Tributo. São Paulo: Ed. Quartier Latin, 2005.

MARTINS, Ives Gandra da Silva. CAMPOS, Dejalma de. GALVÊAS, Ernane. TORRES, Ricardo Lobo. O Tributo. Reflexão multidisciplinar sobre sua natureza. Rio de Janeiro: Ed. Forense, 2007.

TORRES, Ricardo Lobo. Tratado de Direito Constitucional Financeiro e Tributário. Rio de Janeiro: Ed. Renovar, 2009.

UGÁ, Domínguez Vivian. A questão social como "pobreza": crítica à conceituação neoliberal. Tese de doutorado em Ciência Política, apresentada Instituto Universitário de Pesquisas do Rio de Janeiro. 2008. 